\title{
Study of the Association between the Consumption of Dietary Supplements and Lifestyle Factors in a Population of Moroccan Academics during the COVID 19 Health Crisis
}

\author{
Houriya Mestaghanmi ${ }^{*}$, Ali Labriji ${ }^{2}$, Fatima Zahra Kehailou1, Abderazzak Sabri'1, \\ Chaimaa Ait Barka1, Hind Bouzoubaa1, Imane M'Touguy', Mohammed Jabari ${ }^{3}$, Souad El Amrani ${ }^{4}$ \\ ${ }^{1}$ Department of Biology, Laboratory of Physiopathology and Molecular Genetics, Faculty of Sciences Ben M’sik, University Hassan \\ II of Casablanca, Casablanca, Morocco \\ ${ }^{2}$ Department of Computer Mathematics, Laboratory Modeling Analysis and Simulation, Faculty of Sciences Ben M’sik, University \\ Hassan II of Casablanca, Casablanca, Morocco \\ ${ }^{3}$ General Direction of Services, Directorate of Sustainable Development and Urban Life, Prevention and Environmental Health \\ Division, Wilaya of the Casablanca-Settat Region, Ministry of the Interior, Casablanca, Morocco \\ ${ }^{4}$ Department of Biology, Laboratory of Ecology and Environment, Faculty of Sciences Ben M’sik, University Hassan II-Casablanca, \\ Casablanca, Morocco \\ Email: *houriya.mestaghanmi@etu.univh2c.ma
}

How to cite this paper: Mestaghanmi, H., Labriji, A., Kehailou, F.Z., Sabri, A., Barka, C.A., Bouzoubaa, H., M’Touguy, I., Jabari, M. and El Amrani, S. (2021) Study of the Association between the Consumption of Dietary Supplements and Lifestyle Factors in a Population of Moroccan Academics during the COVID 19 Health Crisis. Open Access Library Journal, 8: e7585. https://doi.org/10.4236/oalib.1107585

Received: May 26, 2021

Accepted: June 21, 2021

Published: June 24, 2021

Copyright $\odot 2021$ by author(s) and Open Access Library Inc.

This work is licensed under the Creative Commons Attribution International License (CC BY 4.0).

http://creativecommons.org/licenses/by/4.0/ (c) (i) Open Access

\begin{abstract}
The objective of this study is to determine the prevalence of dietary supplement (DS) consumption by students, their perception of it during Covid 19 confinement, as well as the factors associated with it. A cross-sectional descriptive study was carried out online with a questionnaire, with a population of 350 students from Casablanca (Morocco), from March to May, 2020. The consumption pattern of DS, socio-demographic characteristics and lifestyle were collected. The association between the different factors was made by Pearson's correlation analysis. 69.4\% of participants consume DS of which $32 \%$ are boys and $27.4 \%$ are girls. The most prominent reason for taking DS was to fight fatigue and combat stress (19.8\%), and participants preferred to buy them in pharmacies and drugstores $(55.5 \%)$, on medical prescription. (32.77\%) or on the advice of a pharmacist (7.92\%). 50.60\% consumed vitamins, minerals and/or trace elements, $4.5 \%$ proteins/Amino acids and $4 \%$ fish oils. About a third (35\%) consumed more than one type of supplement at the same time. $45.54 \%$ used them occasionally, $17.92 \%$ regularly and 6.08 frequently. $48.4 \%$ respected the recommended daily doses. Supplementation was significantly associated with body mass index, physical activity, socioeconomic level and is slightly conditioned by dietary practices. $32.5 \%$ think that
\end{abstract}


DS is harmless to health; $21.27 \%$ that regular consumption can prevent some diseases; $46.23 \%$ that excessive consumption can present health risks. These risks could be related to some components of DS. $21.78 \%$ of respondent's experience real satisfaction after consuming DS; $34.65 \%$ feel better; while $2.97 \%$ think they have no effect. Students seemed more likely to consume DS during confinement than the general population, which raises questions related to their impact on health. Thus, awareness campaigns for students on the risks and dangers of these substances are necessary. Strict regulations to ensure their job security are recommended.

\section{Subject Areas}

Public Health, Nutrition

\section{Keywords}

Dietary Supplements (DS), COVID19, Containment, Students, Lifestyle

\section{Introduction}

COVID-19 (SARS-CoV-2) is a disease caused by a new coronavirus, which affects the physical and mental health of individuals in different ways. The ongoing epidemic has been declared by the World Health Organization (WHO) as a global public health emergency [1]. This coronavirus presents a major global human threat that has turned into a pandemic. The latter to SARS-CoV-2 began in China in December 2019, then reached Morocco in March 2020 and has forced several countries, in addition to Morocco, to implement containment of their citizens. This confinement induces a state of significant stress in individuals [2]. Several effects of confinement have been studied by some authors: social isolation, stress, boredom, lack of sleep, anxiety, depression, suicidal and addictive behavior, as well as domestic violence [3]. It also has consequences on the eating habits which are found to be disturbed. Thus, and in the face of this pandemic, the nutritional status of individuals of both sexes, all age groups, in all countries affected by COVID 19, have seen changes and students were not excepted.

Some studies have shown that nutrition has a massive effect on the immune system [4], as well as other bodily systems, improving both the body's protection and the ability to fight the SARS-CoV-2 virus. Polamarasetti and Martirosyan, also noticed in 2020 [4] that some bioactive compounds and functional foods improve the body's immune function and prevent viral infection. These foods can also be recommended in the prevention and early management of chronic and infectious diseases such as SARS-Cov2 [5].

Since the 1980s, attention to meal balance, especially during confinement, has become a significant factor in food choice. Currently, eating behaviors are strongly influenced by the health and nutritional recommendations of physicians, in addition to the role of the media [6]. The subjects are also looking for ways to re- 
duce fatigue and stress, prevent disease, and regain their well-being [7]. As a result, the development of products promising a health effect has also been observed [8]. Healthy foods include dietary supplements (DS). It is for these reasons that some people turn to them, especially those who eat unhealthily, for fear of developing some nutrition-related illnesses [9].

DS are defined according to Directive 2002/46/CE of the European Parliament, transposed by decree $\mathrm{n}^{\circ}$ 2006-352 of March 20, 2006 [10], as "foods tuf DS the purpose of which is to supplement the normal diet and which constitute a concentrated source of nutrients or other substances, having a nutritional or physiological effect". Currently, the promotion of physical and sporting activity for all and throughout life has encouraged subjects to do sport and fitness in sports halls, including wrestling, educating their customers about the new body discipline that encourages DS consumption [11].

The supply of DS has diversified a lot to meet the desires of consumers (compensate for an insufficient daily food intake (Nutrition), help accelerate weight loss or improve the capacity to gain weight and muscles [12] [13], or compensate for a particular condition (fatigue, illness, stress, tone, digestion, beauty, etc.) [8]. It also prevents disease, aim to strengthen health and maintain homeostasis [9]. These substances have increased dramatically in pharmacies, drugstores, organic stores, supermarkets, ... [14].

DS are a priori, healthy substances that present no danger to health. This suggests that each individual can consume them without risk. However, some authors, following studies of their physiological effects, have demonstrated their potentially harmful impact on the functioning of the body [8], especially in the absence of vitamin or mineral deficiencies. Thus, the amount of DS consumed must not exceed the maximum recommended levels. Any excess can be harmful to health [15], especially in the long term. Any supplementation must be under the supervision of a health professional and any intake without supervision may present health risks (overdose or overconsumption or concomitant intake of several DS [16]. In addition, many studies have shown correlations between different pathologies and excessive intake or insufficiency of nutrients [17]. These substances contain active ingredients that could cause side effects, especially when consumed in combination with other drugs or other DS [18], without the supervision of a doctor or pharmacist [19]. It exposes the subject to a risk of drug interactions. Thus, the constituents of DS are likely to increase or inhibit the effect of the drugs concerned. For example, for those intended for athletes aiming for muscle development, their association with analgesics or stimulants may delay the perception of fatigue. In this case, the workouts will be longer or more intense, which increases the risk of developing musculoskeletal disorders [20] and overtraining syndrome.

In Morocco, the placing on the market of DS is subject to control by the Ministry of Health and obeys the same rules as drugs. The DS market has evolved rapidly, especially with changes in lifestyles, the trend of physical well-being, the 
decrease in physical activity which is the cause of the appearance of several diseases (arterial hypertension, diabetes, obesity, etc.), and containment during the COVID19 health crisis. Moroccans consume them either to protect themselves against diseases or health problems (stress, colds, heart attacks, osteoporosis, cancer, dental caries...), or to increase energy, improve physical performance and correct various deficiencies of lifestyle [21]. Thus, Jamal noticed in 2016 that $46 \%$ of Moroccans consume DS more or less regularly. In addition, Khalfaoui observed in 2018 [22], that $34.10 \%$ of Moroccan consumers are students; $33.8 \%$ are civil servants; $24.3 \%$ are executives and $7.8 \%$ have no profession.

Students have particular lifestyles. Student life is a dynamic phase of strong transition, during which the development of the person takes place. Some studies have shown that most of the habits developed by students during this phase determine their current and future state of health. Practices such as sleep deprivation [23], skipping breakfast [24], neglecting to eat meals at fixed and unbalanced times [23], and then compensating for this imbalance with DS, are fairly common practices among university students [25].

Despite the large market for supplements in Morocco, epidemiological studies on the consumption of DS by students are lacking, especially during confinement. Because students have different lifestyles, the use of these substances may differ from that of the general population. Thus, the objectives of the present study are to identify the potential effects of confinement on the consumption of SD by the participants, as well as the factors associated with it. This study will make it possible to develop recommendations.

\section{Population and Methods}

\subsection{Study Context}

Moroccan students are more and more attentive to their well-being and their health, especially during a period of containment put in place in Morocco in mid-March 2020, because of the COVID 19 pandemic. They are also aware of the link between health and food. Thus, they turn to DS to maintain their wellbeing and reduce the risk of disease.

The survey was carried out at the Ben M'Sik Faculty of Sciences, one of the 18 establishments of the Hassan II University in Casablanca. During the 2019-2020 academic year, it was attended by around 12,500 students from several prefectures in the city of Casablanca.

\subsection{Online Survey Procedure}

A cross-sectional, anonymous online descriptive study was carried out from March to May 2020, in accordance with the guidelines of the Helsinki declarations [26], with 350 students from the Ben M'Sik Faculty of Sciences, Casablanca (University Hassan II of Casablanca, Morocco), of different levels of study and background. An email invitation to participate in the survey and containing a link to the online questionnaire was sent to students, March 2020, to have a 
random and non-discriminatory sample.

Inferred consent appeared on the first page of the questionnaire. Students had the right to accept or refuse participation on their own accord.

\subsection{Collection of Data Survey}

The questionnaire was developed and created using "GOOGLE FORMS". The answers added to the questionnaires were collected automatically and organized clearly in a file which is then converted to Excel format.

A pilot study was carried out before the administration of the survey, to confirm the reliability and validity of the questionnaire, on a sample of 50 participants, following which modifications were made to some questions, in order to facilitate their understanding by the surveys.

The investigation gathered information on:

- General questions from the respondents, including socio-demographic information (sex, age, level and course of study, ...) And characteristics of the household (type of housing (luxury, traditional, modern, precarious), size of the household, occupation status (owner, co-owner or tenant)), professions of the parents (civil servant/manager, employee, retired or without profession), ...), anthropometric and lifestyle data (practice of physical activity, use of tobacco, alcohol and drugs, as well as food). Socioeconomic status (good to very good, average, poor) was self-rated by participants.

- The age has been classified into 4 classes: 17 - 21 years; 22 - 24 years old; 25 28 years old and over 28 years old. For the level of studies, the student had 3 choices: License ( $1^{\text {st }}$ year, $2^{\text {nd }}$ year or $3^{\text {rd }}$ year), Masters or Doctorate.

- Anthropometric measurements: The height (height $(\mathrm{cm})$ and weight $(\mathrm{kg})$ of the participants were collected and the body mass index $\left(\mathrm{BMI}\left(\mathrm{kg} / \mathrm{m}^{2}\right)\right)$ was calculated according to WHO recommendations [27] Participants with BMI between 18.5 and 24.99 were considered within the normal weight range, between 25.0 and 29.9 were considered overweight, and those with BMI over 30.0 were considered overweight been classified as obese.

- Regarding lifestyle factors, subjects were classified into 2 categories (yes or no), depending on the state of smoking, alcoholism, or drugs, and physical activity (PA). The intensity of PA expressed in MET (Metabolic Equivalent Task) was calculated by the short version of the international IPAQ questionnaire [28] and the level of PA was determined. This level is considered low if the activity is less than $600 \mathrm{MET}$-minutes/week; moderate if it is between $600-<3000$ MET-minutes/week and high if it is at least $\leq 3000$ METminutes/week).

- Some student eating practices and habits (type of meals consumed, taking the time to prepare the meal, eating a typical meal (starter-main-dessert), eating balanced at the 3 meals of the day and skipping meals...) were studied through a questionnaire.

- The DS consumption mode section consisted of 20 questions. It discussed the different types of DS consumed by participants. These types have been grouped 
into standardized categories (Vitamins/minerals/trace elements, fish oils (Omega 3), proteins/amino acids and DS from plants/plant extracts (Guarana, Ginger, Ginseng...)). In addition, the student use prevalence section had 3 response choices; participants who previously or currently used DS are considered consumers, while those who answered never are considered non-users. It also included questions on the method of consumption (regular, occasional or frequent), the duration of consumption ( 1 year, 2 years, 3 years or 4 years and more), the purchase recommendation (advised by a friend, medical prescription..) and places of purchase (Pharmacies, drugstores, ...), consumer expectations (fight against fatigue and fight stress, maintain health, balance diet, achieve an aesthetic goal, develop muscle mass, or to meet a need related to a PA), the quantities consumed (compliance with the recommended doses), as well as the products used concomitantly.

For students' beliefs about the efficacy and safeties of DS, participants were expected to answer 4 questions: the effectiveness of DS, their health benefits and risk, with excessive consumption, as well as the likely components induce toxicity.

\subsection{Data Analysis}

Statistical analysis was performed using Statistical Package for the Social Sciences (SPSS) Version 25. Quantitative variables were expressed as means, while qualitative variables were expressed as percentages (Number of people with the studied modality/total population). The Chi-square test was used to assess significant differences for categorical characteristics, for example, the relationship between FS consumption and certain variables (sociodemographic, socioeconomic, and some student life factors. The $\mathrm{p}$ value $<0.05$ is considered statistically significant.

\section{Results}

\subsection{Sociodemographic and Lifestyle Characteristics}

The socio-demographic and lifestyle data of the participants are presented in Table 1.

$57.2 \%$ of study participants are girls and $42.8 \%$ are boys, about half of them aged between 17 and 21 (45.1\%). 75.2\% are in License, 12.7\% in Masters and $12.1 \%$ are preparing for their Doctorate. $74 \%$ are studying in biology, $19.2 \%$ in physics, chemistry and $6.5 \%$ in computer mathematics.

$72.28 \%$ live in apartments; $20.79 \%$ of modern housing; $4.95 \%$ in villas; $0.99 \%$ in small traditional houses while $0.99 \%$ in precarious housing. The participants came from families whose self-rated socioeconomic level showed good and very good for $8 \%$, average for $82 \%$ while $10 \%$ are poor.

For the eating habits of the participants, almost half of the students $(47.54 \%)$ prefer a healthy diet. Thus, $35.65 \%$, declare consuming meals prepared at home and $11.89 \%$, complete meals (starter, main course and dessert). $17.82 \%$ eat fast 
Table 1. Characteristics of the study population.

\begin{tabular}{|c|c|}
\hline Variables & Percentage (\%) \\
\hline \multicolumn{2}{|l|}{ Gender } \\
\hline Female & $57.2 \%$ \\
\hline Male & $42.8 \%$ \\
\hline \multicolumn{2}{|l|}{ Age (years): } \\
\hline $17-21$ & $45.1 \%$ \\
\hline $22-24$ & $36.6 \%$ \\
\hline $25-28$ & $12.1 \%$ \\
\hline Over 28 & $6.2 \%$ \\
\hline \multicolumn{2}{|l|}{ Level of studies: } \\
\hline Licence & $75.2 \%$ \\
\hline Master & $12.7 \%$ \\
\hline $\mathrm{PhD}$ & $12.1 \%$ \\
\hline \multicolumn{2}{|l|}{ Study stream } \\
\hline Biology & $74 \%$ \\
\hline Chemical Physics & $19.2 \%$ \\
\hline Computer science & $6.8 \%$ \\
\hline \multicolumn{2}{|c|}{ Parents' self-estimated socioeconomic level: } \\
\hline Good and very good & $8 \%$ \\
\hline Way & $82 \%$ \\
\hline Poor & $10 \%$ \\
\hline \multicolumn{2}{|l|}{ Body mass index $\left(\mathrm{kg} / \mathrm{m}^{2}\right)$} \\
\hline Underweight (Below 18.49) & $8.15 \%$ \\
\hline Normal corpulence $(18.5$ - 24.9) & $65.35 \%$ \\
\hline Overweight $(25.0$ - 29.9) & $22.69 \%$ \\
\hline Obesity (Greater than 30) & $3.81 \%$ \\
\hline \multicolumn{2}{|c|}{ Practice of Physical Activity (PA) during the last 12 months } \\
\hline No & $30.7 \%$ \\
\hline Yes & $69.3 \%$ \\
\hline - Low & $22.7 \%$ \\
\hline Moderate & $31 \%$ \\
\hline High & $15.6 \%$ \\
\hline \multicolumn{2}{|l|}{ Alcoholism } \\
\hline Yes & $3.2 \%$ \\
\hline No & $96.8 \%$ \\
\hline \multicolumn{2}{|l|}{ Smoking } \\
\hline Yes & $14.5 \%$ \\
\hline No & $85.5 \%$ \\
\hline
\end{tabular}




\section{Continued}

\begin{tabular}{|c|c|c|}
\hline \multicolumn{3}{|c|}{ Drugs } \\
\hline & Yes & $1.5 \%$ \\
\hline & No & $98.5 \%$ \\
\hline \multicolumn{3}{|c|}{ Eating habits: } \\
\hline \multicolumn{3}{|c|}{ - $\quad$ Consumption of balanced meals } \\
\hline & Breakfast & $39.6 \%$ \\
\hline & Lunch & $35.64 \%$ \\
\hline & Having dinner & $38.6 \%$ \\
\hline \multicolumn{3}{|c|}{ - $\quad$ Type of meal consumed } \\
\hline & Prepared at home & $35.65 \%$ \\
\hline \multicolumn{2}{|c|}{ Complete meal (Starter, main course and dessert) prepared at home } & $11.89 \%$ \\
\hline & Sandwich & $30.69 \%$ \\
\hline & Fast food & $17.82 \%$ \\
\hline \multicolumn{3}{|c|}{ - $\quad$ Skipping meals } \\
\hline & Never & $6 \%$ \\
\hline & Sometimes & $43 \%$ \\
\hline & Often enough & $51 \%$ \\
\hline
\end{tabular}

food and $2.97 \%$ declare consuming several types of meal. Generally, the respondents are losing their nutritional balance. Approximately, a third of the population still consumes balanced and structured meals (39.6\% at breakfast; $35.64 \%$ at lunch and $38.6 \%$ at dinner); half sometimes eat balanced meals (39.6\% at breakfast; $54.5 \%$ at lunch and $47.5 \%$ at dinner), while the rest of the students never eat a balanced diet (20.8\% at breakfast; $9.9 \%$ at lunch and $13.9 \%$ at dinner). The majority of respondents have poor eating habits, especially irregular meal consumption. Thus, $51 \%$ say they often skip meals and $43 \%$ from time to time (Table 1).

\subsection{DS Consumption Mode}

The characteristics of DS consumption by students are shown in Table 2 .

Of the 350 participants in the survey, $69.4 \%$ reported consuming DS, with roughly similar consumption in both sexes (35.4\%) are boys and $34 \%$ are girls) $\left(\mathrm{Khi}^{2}=2.37 ; \mathrm{p}=0.512\right)$. The highest prevalence of consumption was observed among students aged 17 to $24(41 \%)\left(\mathrm{p}=0.001 ; \mathrm{Khi}^{2}=4.68\right)$. No association was observed between DS consumption and level of education $\left(\mathrm{Chi}^{2}=3.505 ; \mathrm{p}=\right.$ 0.477). On the other hand, the majority of consumers (51\%) of these substances follow their studies in Life sciences, but without statistically significant difference between the different channels $\left(\mathrm{Khi}^{2}=4.8 ; \mathrm{p}=0.09\right)$.

This consumption is associated with the socio-economic level of the parents of the students. Thus, the participants who consume them the most are those 
Table 2. Summary of the mode of DS consumption in the surveyed population.

\begin{tabular}{|c|c|c|}
\hline Variables & Choice of answer & Percentage (\%) \\
\hline \multirow[b]{2}{*}{ Consumption Dietary supplements } & Yes & $69.4 \%$ \\
\hline & No & $30.6 \%$ \\
\hline \multirow{3}{*}{ Frequency of consumption } & Occasional & $45.5 \%$ \\
\hline & Regular & $17.92 \%$ \\
\hline & Frequent & $6.08 \%$ \\
\hline \multirow{5}{*}{ Duration of consumption } & 4 years and over & $11.88 \%$ \\
\hline & 3 years & $4.95 \%$ \\
\hline & 2 years & $7.92 \%$ \\
\hline & 1 year & $26.83 \%$ \\
\hline & Don't know how to answer & $17.82 \%$ \\
\hline \multirow{2}{*}{$\begin{array}{l}\text { Respect of the daily dose of } \\
\text { dietary supplements consumed }\end{array}$} & Yes & $48.4 \%$ \\
\hline & No & $21 \%$ \\
\hline \multirow{6}{*}{ Purchase recommendation } & On medical prescription & $22.77 \%$ \\
\hline & On the advice of a dietitian & $1.98 \%$ \\
\hline & On the advice of an athlete & $0.99 \%$ \\
\hline & On the advice of a pharmacist & $20.79 \%$ \\
\hline & On the advice of a friend or relative & $7.92 \%$ \\
\hline & Media, Advertising & $4.95 \%$ \\
\hline \multirow{4}{*}{ Place of purchase } & At a nutritionist & $1.99 \%$ \\
\hline & In specialized stores & $7.94 \%$ \\
\hline & In pharmacies and drugstores & $55.5 \%$ \\
\hline & On the Internet & $3.97 \%$ \\
\hline \multirow{7}{*}{ Reason for consumption } & Fight fatigue and combat stress & $21.34 \%$ \\
\hline & Balancing the diet & $10.5 \%$ \\
\hline & Maintaining health & $3.96 \%$ \\
\hline & To achieve an aesthetic goal & $6.95 \%$ \\
\hline & To build muscle mass & $4.5 \%$ \\
\hline & To fill a need related to a sports activity & $4.23 \%$ \\
\hline & $\begin{array}{l}\text { Multiple reasons (maintenance of health, } \\
\text { weight loss, beauty, disease prevention) }\end{array}$ & $7.92 \%$ \\
\hline \multirow{5}{*}{ Type of Dietary supplement } & Vitamins/Minerals/Trace elements & $40.6 \%$ \\
\hline & Proteins/Amino acids & $4.5 \%$ \\
\hline & Fish oil (Omega 3) & $4 \%$ \\
\hline & DS Herbal/Herbal Extract & $4.3 \%$ \\
\hline & DS targeting a particular problem & $6 \%$ \\
\hline Non-consumers of DS & - & $40.6 \%$ \\
\hline \multirow{2}{*}{$\begin{array}{l}\text { Compliance with the daily } \\
\text { dose of DS consumed }\end{array}$} & Yes & $48.4 \%$ \\
\hline & No & $11 \%$ \\
\hline
\end{tabular}


whose parents have a good socioeconomic level $\left(\mathrm{Khi}^{2}=9.17 ; \mathrm{p}=0,014\right)$. On the other hand, it is associated neither with smoking $\left(\mathrm{Khi}^{2}=2.35 ; \mathrm{p}=0.12\right)$, nor alcoholism $\left(\left(\mathrm{Khi}^{2}=0.79 ; \mathrm{p}=0.37\right)\right.$, nor with drugs $\left(\mathrm{Khi}^{2}=2.43 ; \mathrm{p}=0.11\right)$. It is also slightly conditioned by dietary practices. It seems that the consumption of DS influence the type of meal consumed $\left(\mathrm{Khi}^{2}=17.81 ; \mathrm{p}=0.037\right)$, and balanced eating $\left(\mathrm{Khi}^{2}=6.486 ; \mathrm{p}=0.039\right)$. However, it does not influence the skipping of meals $\left(\mathrm{Khi}^{2}=3.23 ; \mathrm{p}=0.19\right)$.

The frequency of DS consumption varies depending on the student. It was reported as once/day for 38\%, 2 times/day for 10\%, 3 times/day for $9.4 \%$, or more than 3 times/day for $12 \%\left(\mathrm{Chi}^{2}=65.885 ; \mathrm{p}=0.023\right)$. About half of the respondents $(48.4 \%)$ respect the recommended daily dose. $45.54 \%$ are occasional consumers (consumption during the exam period or seasonal change); $17.92 \%$ consume them regularly and $6.08 \%$ frequently $\left(\mathrm{Chi}^{2}=36.757 ; \mathrm{p}=0.000\right)$.

The duration of DS consumption varies depending on the participants. About a third of students (26.83\%) have been consuming DS for 1 year; $7.92 \%$ for 2 years; $4.95 \%$ for 3 years and $11.88 \%$ for 4 years and more and $17.82 \%$ could not answer because they don't no longer remember the date of the start of consumption of these substances, which probably exceeds the 4 years $\left(\mathrm{Chi}^{2}=17.055 ; \mathrm{p}=\right.$ $0.004)$.

$30.6 \%$ of respondents do not consume these substances for several reasons. $16.73 \%$ say they do not feel the need for it; $5.94 \%$ because of the lack of confidence in these products; $3.96 \%$ because of their too high price; $0.99 \%$ because of their bad taste and $2.98 \%$ for multiple reasons.

The purchase of DS is influenced in $4.95 \%$ of respondents by the media and advertising; $20.79 \%$ buy them on the advice of a pharmacist; $32.77 \%$ on medical prescription; $7.92 \%$ on the advice of a relative or friend; $1.98 \%$ on the advice of a dietitian and $0.99 \%$ on the advice of an athlete ( $0.99 \%$ of boys $)\left(\mathrm{Khi}^{2}=35.82 ; \mathrm{p}=\right.$ 0.000). $55.5 \%$ buy them in pharmacies and drugstores; $7.94 \%$ in specialized stores; $3.97 \%$ on the internet and $1.99 \%$ among nutritionists $\left(\mathrm{Khi}^{2}=32.219 ; \mathrm{p}=\right.$ $0.000)$.

40.6\% have preferences for Vitamins/Minerals/trace elements; $4.5 \%$ Protein/ amino acids; $4 \%$ Fish oils (Omega 3); $4.3 \%$ the DS based on plants/plant extracts (Ginseng, Guarana, Biloba...) While 6\% for those targeting particular problems (anti-aging, anti-stress, beauty, sleep, intestinal transit...), without statistically difference significant between the two sexes $\left(\mathrm{Khi}^{2}=17.42 ; \mathrm{p}=0.49\right)$, nor as a function of age $\left(\mathrm{Khi}^{2}=68.09 ; \mathrm{p}=0.09\right)$ (Figure 1). It was also observed that, $35 \%$ of participants consume more than one type of DS.

The percentage of consumers who took more than one type of supplement (35\%), divided by the total number of consumers $\times 100$ ), is $50.43 \%$ ( $18 \%$ of men, $32.43 \%$ of women). Women are therefore more likely to take more than one type of dietary supplement than men.

$21.78 \%$ of respondent's experience real satisfaction after consuming DS; $24.65 \%$ feel better; while $12.97 \%$ think they do not feel at all better $\left(\mathrm{Chi}^{2}=2.217\right.$; $\mathrm{p}=0.330$ ). The main reason for consumption is the fight against fatigue and the 


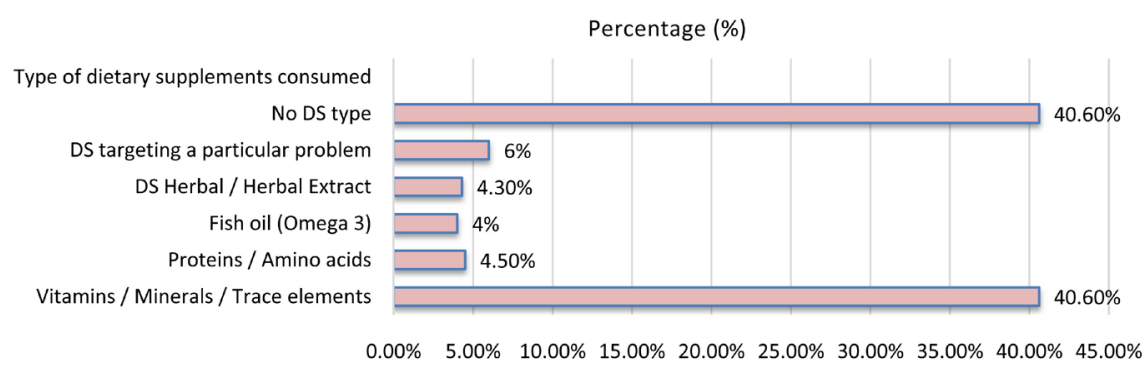

Figure 1. Distribution of participants according to the type of turnover consumed.

fight against stress (31.34\%); $10.5 \%$ to balance the diet with nutrients; $6.95 \%$ to achieve an aesthetic goal; $4.5 \%$ to build muscle mass; $4.23 \%$ consume them to meet the need for sports activity, while $7.92 \%$ for multiple reasons (maintenance of health, weight loss, beauty, disease prevention $)\left(\mathrm{Khi}^{2}=41.741 ; \mathrm{p}=0.002\right)$ (Figure 2).

We observe that the majority of participants who consume DS to fight fatigue and combat stress and achieve an aesthetic goal are girls, while those who consume them to meet a need related to a sporting activity and develop muscle mass are practically all boys $\left(\mathrm{Khi}^{2}=31.54 ; \mathrm{p}=0.041\right)$.

Regarding participants belie DS about DS, 32.5\% think they are harmless to health, $21.27 \%$ that their regular consumption can prevent some diseases (deficiencies, chronic diseases, cancer, etc.) while for $46.23 \%$, their excessive consumption can present health risks. According to the students, DS can cause potential harmful side effects such as bone problems (27.7\%), hypervitaminosis (22.8\%), with the development of some type of cancer (lung cancer) (15.84\%), cardiovascular disorders (risk of cardiac arrest, etc.) (10.89\%), renal dysfunction problems (9.9\%), allergies (6.93\%), hepatic dysfunction (3.96\%), as well as the risk of mortality (1.98\%) (Figure 3).

Participants believe that these health risks could be due to some components of these substances. Thus, a third of them (30\%) think that the toxicity is linked to the food additives used in their manufacture, $21 \%$ to some vitamins (C, D, E or beta-carotene), $15 \%$ to antioxidants; $15 \%$ with several components (vitamins, minerals, plant extracts...); $10 \%$ to herbal products, while the remainder of the students think that minerals (2\%), amino acids (5\%) and proteins (2\%) are very harmless (Table 3).

In the study population, $69.3 \%$ participated in sport. The level of PA is low for 22.7\%; moderate for $31 \%$ and high for $25.6 \%$ (Figure 4 ). The most active are those aged between 17-21 years $(\mathrm{p}=0.000)$. DS consumption was not just for athletes. Thus $11.3 \%$ of consumers are non-athletic and $54 \%$ have practiced physical activity during the past 12 months. Sport participation was associated with a higher probability of DS consumption $\left(\mathrm{Chi}^{2}=13.16 ; \mathrm{p}=0.000\right)$, as well as type of DS ( $p=0.007)$. This consumption is also associated with the level of physical activity $\left(\mathrm{Chi}^{2}=10.94 ; \mathrm{p}=0.0027\right)$. It is more important when this level increases (Figure 4). Overall, those who are very physically active tended to prefer 


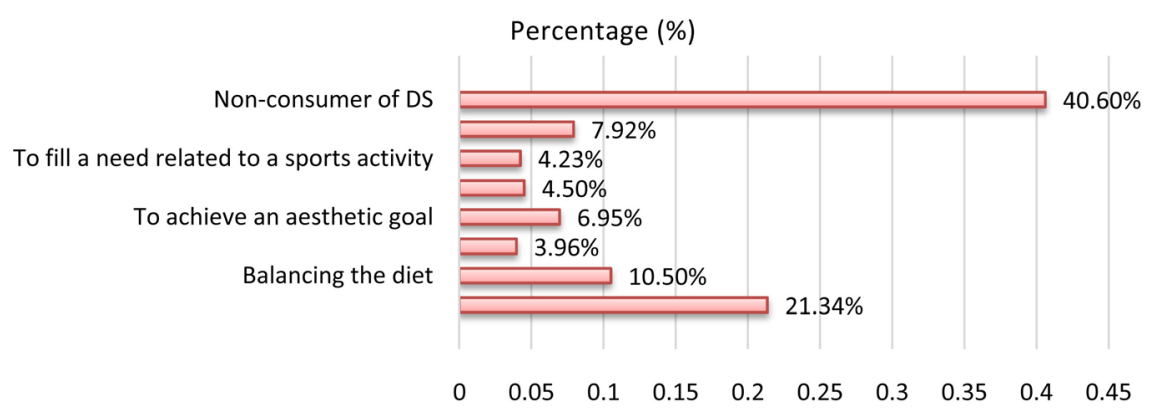

Figure 2. Distribution of the population according to the reason for consuming DS.

$\begin{array}{ll}\square \text { Bone problems } & \text { Hypervitaminosis } \\ \square \text { Development of some types of cancer } & \text { Cardiovascular disorders (risk of cardiac arrest, etc.) } \\ \square \text { Kidney dysfunction } & \text { Liver dysfunction } \\ \square \text { Allergies } & \text { Mortality risk }\end{array}$

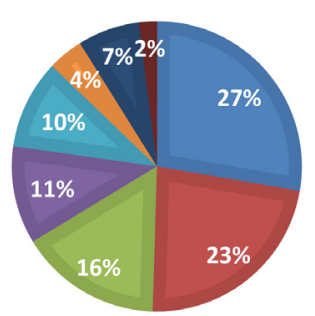

Figure 3. Beliefs of participants regarding the consumption of DS.

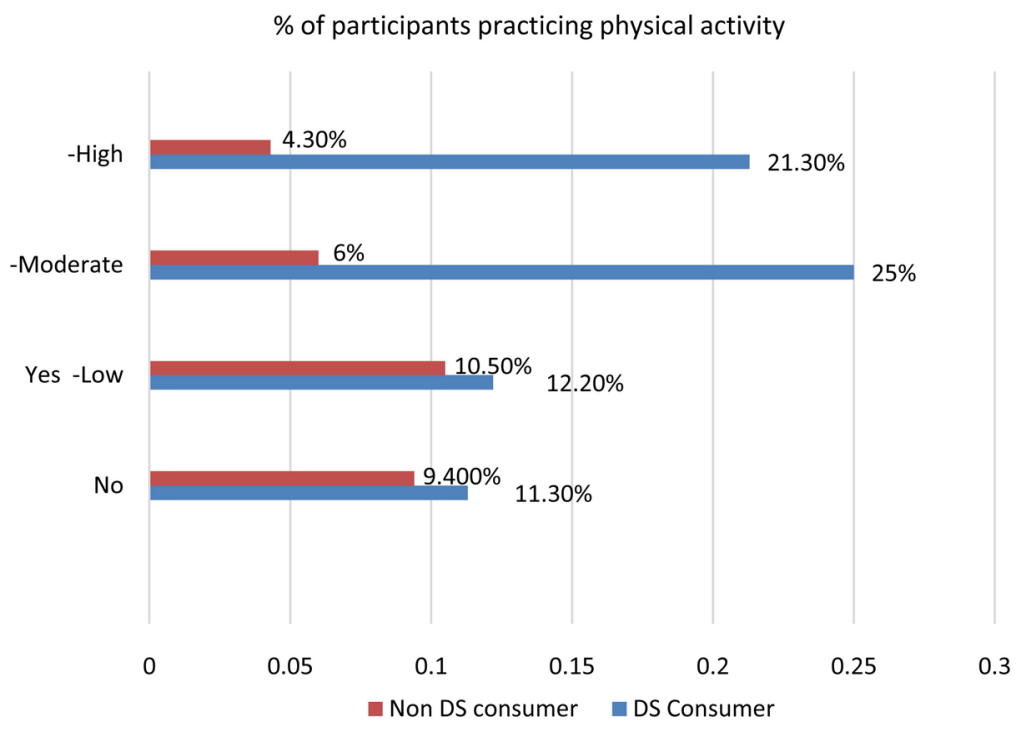

Figure 4. Distribution of participants according to DS consumption and level of physical activity (PA).

vitamins/minerals or trace elements. It also appears from this study that people who do not use tobacco, drugs or alcohol practically all consume DS.

The average BMI is $22.64 \mathrm{~kg} / \mathrm{m}^{2} \pm 3.94 .65 .35 \%$ of respondents have a normal BMI (between 18 and $24.9 \mathrm{~kg} / \mathrm{m}^{2}$ ), $8.15 \%$ are underweight (less than 18.49 ), $22.69 \%$ are overweight $(25.0-29.9)$ and $3.81 \%$ obesity (Greater than 30$)$. BMI 
Table 3. Student beliefs about some components of DS.

\begin{tabular}{cc}
\hline Components of DS & Percentage (\%) \\
\hline Some food additives & $30 \%$ \\
Vitamins (C, D, E or beta-carotene) & $21 \%$ \\
Minerals & $2 \%$ \\
Products based on plant extracts & $10 \%$ \\
Antioxidants & $15 \%$ \\
Some amino acids (glutamine, arginine, etc.) & $5 \%$ \\
Protein & $2 \%$ \\
Several components (Vitamin C, D, E or beta-carotene), \\
minerals, Antioxidants, some food additives, plant extract)
\end{tabular}

varies according to sex $\left(\mathrm{p}=0.000 ; \mathrm{Khi}^{2}=31.67\right)$ and according to age groups ( $\mathrm{p}$ $=0.021$ ).

An association is observed between DS consumption and BMI $\left(\mathrm{Chi}^{2}=21.88 ; \mathrm{p}\right.$ $=0.000$ ) (Table 4). Those who are underweight hardly consume DS. In contrast, the majority of those with a normal or overweight BMI consume DS (Figure 5).

For the perception of the general state of health (physical and mental), overall consumers of DS feel in better state of health than non-consumers, but without statistically significant difference between the two groups $\left(\mathrm{Khi}^{2}=1.25 ; \mathrm{p}=0.60\right)$.

\section{Discussion}

In students, good eating habits are essential for maintaining good health, good memorization and learning skills, as well as for meeting the body's nutrient needs. Inadequate food intake leads to vitamin and mineral deficiencies and can lead to the development of food-related illnesses. As a result, the consumption of DS is becoming more and more common to balance the diet and maintain good health [29]. Data on DS consumption by students in Morocco is very limited, especially during the lockdown period.

It appears from this study that $69.4 \%$ of participants consume DS, of which $35.4 \%$ are boys and $34 \%$ are girls, without significant differences between the two sexes $\left(\mathrm{Khi}^{2}=2.37 ; \mathrm{p}=0.51\right)$. These substances are therefore widely consumed by young Moroccans, because they take more and more care of their health and their diet. Nevertheless, the apparent overuse of these substances by participants is of particular concern, because many habits established during high school and higher education appears to be more persistent throughout life [30]. This result agrees with that of Sirico et al. [31], but it is higher than that observed by Jamal in 2016 (46\%) and Khalfaoui in 2018 (57.1\%) in Morocco [22], with higher DS consumption among girls. Several studies have shown this female predominance [32] [33]. On the other hand, Braun and Venter [34] found that higher education and young age were associated with supplement consumption and that gender was very influential. 
Table 4. Summary of the association of DS consumption with some parameters studied.

\begin{tabular}{|c|c|c|c|c|}
\hline & Characteristics & $\begin{array}{c}\text { DS } \\
\text { consumers }\end{array}$ & $\begin{array}{c}\text { Non DS } \\
\text { consumers }\end{array}$ & $\begin{array}{c}\mathrm{Khi}^{2} ; \\
\text { p Value }\end{array}$ \\
\hline \multicolumn{5}{|c|}{ Age } \\
\hline- & $17-21$ years & $36 \%$ & $17 \%$ & \multirow{4}{*}{$\begin{array}{c}\mathrm{Khi}^{2}=4.68 \\
\mathrm{p}=0.001\end{array}$} \\
\hline- & $22-24$ & $17.25 \%$ & $3 \%$ & \\
\hline- & $25-28$ & $8 \%$ & $9 \%$ & \\
\hline- & Over 28 years & $8 \%$ & $1.6 \%$ & \\
\hline \multicolumn{5}{|c|}{ Gender: } \\
\hline & Girls & $54 \%$ & $3.2 \%$ & \multirow[t]{2}{*}{$\begin{array}{c}\mathrm{Khi}^{2}=2.37 \\
\mathrm{p}=0.512\end{array}$} \\
\hline & Boys & $12.8 \%$ & $30 \%$ & \\
\hline \multicolumn{5}{|c|}{ Education level } \\
\hline- & License & $50 \%$ & $27 \%$ & \multirow{3}{*}{$\begin{array}{c}\mathrm{Khi}^{2}=3.505 \\
\mathrm{p}=0.477\end{array}$} \\
\hline- & Master & $2 \%$ & $1 \%$ & \\
\hline- & Doctorate & $15 \%$ & $5 \%$ & \\
\hline \multicolumn{5}{|c|}{ Sector: } \\
\hline & Biology & $49 \%$ & $24 \%$ & \multirow{3}{*}{$\begin{array}{c}\mathrm{Khi}^{2}=4.8 \\
\mathrm{p}=0.095\end{array}$} \\
\hline & Chemical Physics & $13 \%$ & $7 \%$ & \\
\hline \multicolumn{2}{|c|}{ Mathematics Computer Science } & $5 \%$ & $2 \%$ & \\
\hline \multicolumn{5}{|c|}{ BMI Classes: } \\
\hline- & Underweight & $2 \%$ & $8 \%$ & \multirow{4}{*}{$\begin{array}{c}\mathrm{Khi}^{2}=21.88 \\
\mathrm{p}=0.000\end{array}$} \\
\hline- & Normal build & $42 \%$ & $25 \%$ & \\
\hline- & Overweight & $20 \%$ & $0 \%$ & \\
\hline- & Obesity & $3 \%$ & $0 \%$ & \\
\hline \multicolumn{5}{|c|}{ Socio-economic level: } \\
\hline- & Very Good & $7 \%$ & $1 \%$ & \multirow{3}{*}{$\begin{array}{c}\mathrm{Khi}^{2}=9.17 \\
\mathrm{p}=0.014\end{array}$} \\
\hline- & Way & $57 \%$ & $25 \%$ & \\
\hline- & Poor & $3 \%$ & $7 \%$ & \\
\hline \multicolumn{4}{|c|}{ Tobacco consumption: } & \multirow{3}{*}{$\begin{array}{c}\mathrm{Khi}^{2}=2.35 \\
\mathrm{p}=0.12\end{array}$} \\
\hline & No & $67 \%$ & $32 \%$ & \\
\hline & Yes & $0 \%$ & $1 \%$ & \\
\hline \multicolumn{4}{|c|}{ Alcohol consumption: } & \multirow{3}{*}{$\begin{array}{c}\mathrm{Khi}^{2}=0.79 \\
\mathrm{p}=0.37\end{array}$} \\
\hline & No & $65 \%$ & $31 \%$ & \\
\hline & Yes & $2 \%$ & $2 \%$ & \\
\hline \multicolumn{4}{|c|}{ Drug use: } & \multirow{3}{*}{$\begin{array}{c}\mathrm{Khi}^{2}=2.43 \\
\mathrm{p}=0.11\end{array}$} \\
\hline & No & $67 \%$ & $31 \%$ & \\
\hline & Yes & $0 \%$ & $1 \%$ & \\
\hline
\end{tabular}




\section{Continued}

\begin{tabular}{|c|c|c|c|}
\hline \multicolumn{3}{|l|}{ Practice of physical activity: } & \multirow{3}{*}{$\begin{array}{c}\mathrm{Khi}^{2}=12.94 \\
\mathrm{p}=0.000\end{array}$} \\
\hline No & $16 \%$ & $20 \%$ & \\
\hline Yes & $51 \%$ & $13 \%$ & \\
\hline \multicolumn{3}{|l|}{ Type of meal consumed: } & \multirow{6}{*}{$\begin{array}{c}\mathrm{Khi}^{2}=17.81 \\
\mathrm{p}=0.037\end{array}$} \\
\hline Prepared at home & $26 \%$ & $9.65 \%$ & \\
\hline $\begin{array}{l}\text { Complete meal (Starter. main course } \\
\text { and dessert) home made }\end{array}$ & $9 \%$ & $2.89 \%$ & \\
\hline Sandwich & $17 \%$ & $11.69 \%$ & \\
\hline Sandwich & $12 \%$ & $5.82 \%$ & \\
\hline Don't know how to remunerate & $5.4 \%$ & $0.55 \%$ & \\
\hline \multicolumn{3}{|l|}{ Do you think you are eating a balanced diet: } & \multirow{4}{*}{$\begin{array}{c}\mathrm{Khi}^{2}=17.80 \\
\mathrm{p}=0.037\end{array}$} \\
\hline Always & $26 \%$ & $14 \%$ & \\
\hline Sometimes & $32 \%$ & $16 \%$ & \\
\hline Never & $11 \%$ & $3 \%$ & \\
\hline \multicolumn{3}{|l|}{ Skipping meal: } & \multirow{4}{*}{$\begin{array}{c}\mathrm{Khi}^{2}=3.23 \\
\mathrm{p}=0.19\end{array}$} \\
\hline No & $\%$ & $0 \%$ & \\
\hline Sometimes & $26 \%$ & $17 \%$ & \\
\hline Often & $35 \%$ & $16 \%$ & \\
\hline \multicolumn{3}{|l|}{ Type DS: } & \multirow{6}{*}{$\begin{array}{c}\mathrm{Khi}^{2}=17.42 \\
\mathrm{p}=0.49\end{array}$} \\
\hline Vitamins/Minerals/Trace elements & $40.6 \%$ & _- & \\
\hline Proteins/Amino acids & $4.5 \%$ & & \\
\hline Fish oil (Omega 3) & $4 \%$ & & \\
\hline DS Herbal/Herbal Extract & $4.3 \%$ & & \\
\hline DS targeting a particular problem & $6 \%$ & & \\
\hline \multicolumn{3}{|l|}{ Frequency of consumption: } & \multirow{4}{*}{$\begin{array}{c}\mathrm{Khi}^{2}=65.885 \\
\mathrm{p}=0.023\end{array}$} \\
\hline Occasionnelle & $45.5 \%$ & - & \\
\hline Régulière & $17.92 \%$ & & \\
\hline Fréquente & $6.08 \%$ & & \\
\hline \multicolumn{3}{|l|}{ Duration of consumption: } & \multirow{5}{*}{$\begin{array}{c}\mathrm{Khi}^{2}=17.05 \\
\mathrm{p}=0.004\end{array}$} \\
\hline 1 year & $26.83 \%$ & - & \\
\hline 2 years & $7.92 \%$ & & \\
\hline 3 years & $4.95 \%$ & & \\
\hline 4 years and over & $11.88 \%$ & & \\
\hline \multicolumn{3}{|l|}{ Purchase recommendation: } & \multirow{7}{*}{$\begin{array}{c}\mathrm{Khi}^{2}=35.82 \\
\mathrm{p}=0.000\end{array}$} \\
\hline Media and advertising & $4.95 \%$ & - & \\
\hline Advice from a pharmacist & $20.79 \%$ & & \\
\hline Medical prescription & $32.77 \%$ & & \\
\hline Parent or friend advice & $7.92 \%$ & & \\
\hline Dietitian Council & $1.98 \%$ & & \\
\hline Sports advice & $0.99 \%$ & & \\
\hline
\end{tabular}




\section{Continued}

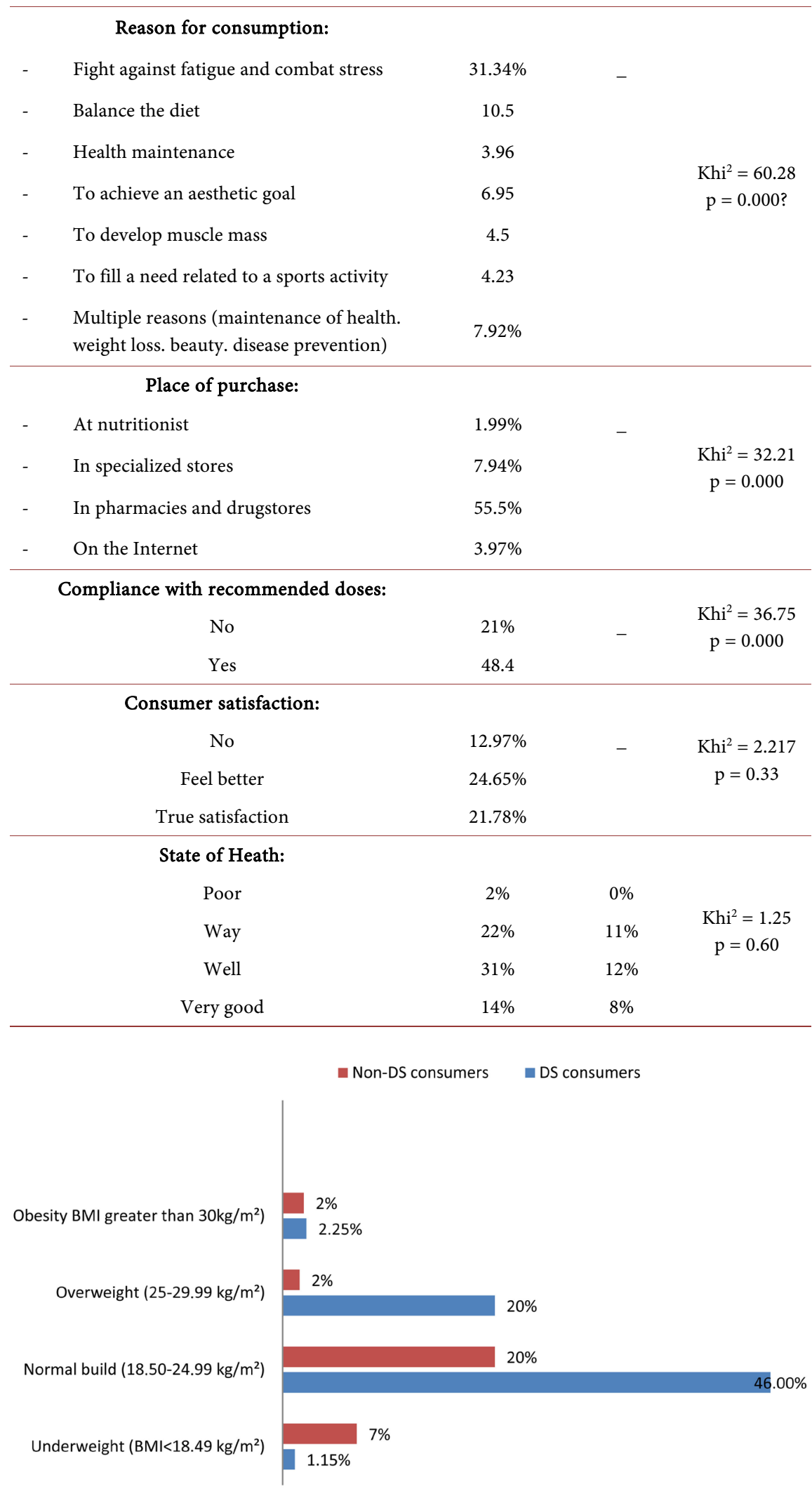

Figure 5. Distribution of participants according to DS consumption and according to BMI classes. 
The highest prevalence of DS consumption is observed among students aged $17-24(41 \%) \cdot \mathrm{p}=0.001)\left(\mathrm{Chi}^{2}=4.681\right)$, so, a trend in DS consumption by the youngest participants. This result agrees with those observed by Sirico et al. [31] among Italian students, Dubecq et al. [35], CREDOC [32], as well as that of Khalfaoui [22], which found in Morocco that heavy users of these substances were between 20 and 30 years old (51\%). It should also be noted that the participants who consume DS occasionally (to solve health problems during exams, to combat stress, and to achieve an aesthetic goal) are all girls, while those who consume them to meet their needs. A need related to sports activity and to increase muscle mass are all boys. This shows the difference in consumption between the two sexes. Several studies have shown this difference in the acquisition, preparation and consumption of food, between food choices and nutritional strategy. There are therefore reciprocal interactions between sex and food, which are conditioned by physiological, psychological and socio-cultural factors. Women show more confidence in a healthy diet and a greater uncontrollable commitment to body weight [36].

$48.4 \%$ of the population declares that they comply with the recommended daily dose; this reflects the importance of the recommendations mentioned in the prospectuses. An underdose will have no effect on health, while an overdose may lead to unwanted effects, such as disturbance of body homeostasis, with side effects [37].

$30.6 \%$ of participants do not consume DS, of which $16.73 \%$ do not feel the need, $5.94 \%$ do not trust these products and $3.96 \%$ because of their high price. The majority of non-consumers therefore believe that a healthy diet is capable of meeting their nutritional needs; Indeed, Bonillo [38] found that $42 \%$ of nonconsumers of French DS doubt the usefulness of DS. Also, the prices of these substances are so exorbitant that they prohibit their purchase by students, the majority of whom do not have stock exchanges and whose financial means are very limited.

This consumption is not associated with smoking $\left(\mathrm{Khi}^{2}=2.35 ; \mathrm{p}=0.12\right)$, alcoholism $\left(\mathrm{Khi}^{2}=0.79 ; \mathrm{p}=0.37\right)$, and drugs $\left(\mathrm{Khi}^{2}=2.43 ; \mathrm{p}=0.11\right)$, but it is associated with the socio-economic level of the parents of the participants $\left(\mathrm{Khi}^{2}=\right.$ 9.17; $\mathrm{p}=0.014)$. The respondents who consume them the most are those whose parents have good incomes. Khalfaoui (2018) [22] also noted that Moroccan supplement consumers were more educated and had a higher socio-economic status. In contrast, Al-Johani et al. [39] found no association between substance use and social status among students from Saudi Arabia.

This consumption of DS is also slightly conditioned by dietary practices. Thus, the consumption of DS influences the type of meal consumed $\left(\mathrm{Khi}^{2}=\right.$ $17.81 ; \mathrm{p}=0.037)$, and balanced eating $\left(\mathrm{Khi}^{2}=6.486 ; \mathrm{p}=0.039\right)$. However, it does not affect skipping meals $\left(\mathrm{Chi}^{2}=3.23 ; \mathrm{p}=0.19\right)$. Changes in the eating behavior of students have also been observed by Agathe in France [40]. Good eating habits among young people and especially students are determining factors for learning capacities. 
It appears from this study that $40.6 \%$ have preferences for vitamin and mineral type DS, of which $7.92 \%$ are boys and $34.65 \%$ are girls. Indeed, the consumption of vitamins and minerals is a fairly common attitude among young people, especially among people who are very concerned about their overall health [31] [41]. Similar results were observed by Sirico et al. [31] among Italian students. This type of DS claims to provide the energy and the ability to engage in typical daily activities without getting tired, a concept closer to mental than physical energy or caloric intake [42]; 0'Connor [43]. Vitamins and minerals play an essential role in the body, improve stress, have a positive effect on mood, help fight infections by strengthening the body, intervene in the repair of damaged tissues, prevent aging premature and the appearance of some diseases (cancers, etc.). Trace elements are also involved in many biochemical and metabolic reactions. They are widely used as anti-stress and to reduce fatigue.

Very few students $(4.5 \%)$ consume DS made from proteins and amino acids, most of which are boys who want to increase muscle mass and improve physical performance. $4.5 \%$ consume Omega 3 and $4.3 \%$ of plant-based DS. Omega 3 plays a role in the protection of the cardiovascular system, skin, hair and nails and is very important in cell renewal. It is necessary for normal brain function and mental health, and is involved in the regulation of blood pressure. Omega 3 improves stress, either alone or when combined with trace elements, antioxidants that prevent their degradation and maximize their effects, or with vitamins [44]. Plants or plant extracts are used as energizers (Ginseng...), but also to increase muscle mass (proteins/amino acids) or to lose weight. Currently, the use of herbal extracts as adjuncts to weight loss diets is a growing practice. However, more often than not, the clinical efficacy of these supplements is still unsome [45]. These are usually substances of plant origin, which moderate appetite and which may help reduce the feeling of "appetite suppressant" hunger. This type of supplement also has the particularity of reducing the activity of digestive enzymes, and therefore reducing the intestinal absorption of sugars. Thus, they inhibit hyperglycemia and postprandial insulinemia, and consequently induce the reduction of "pecks" [14]. For all these reasons, the use of these substances should be under the guidance of a healthcare professional.

Regarding the frequency of DS consumption, $45.54 \%$ are occasional consumers (of which $25.74 \%$ consume them from time to time very irregularly), while $17.92 \%$ regularly and $6.08 \%$ frequently. Quite often, occasional consumption takes place during exam periods, (to combat fatigue, intense stress, combat memory loss and improve concentration), or during the period of seasonal changes in the form of cures. In France, the cure takes place in winter for 54\% of adult consumers and $70 \%$ of children [46]. This occasional DS consumption by our participants is lower than that observed by Khalfaoui (79.5\%) in 2018 [22] and Jamal in $2016(84.1 \%)$ in Morocco [11], as well as by Devaux and Brisard in France in $2016(43 \%)$ [47].

For the duration of DS consumption, it varies according to the participants, but $26.83 \%$ have consumed them for 1 year; $7.92 \%$ for 2 years. So the majority 
have been consuming them for a long time, because they need them. To be able to assimilate new data every day, students must have a healthy brain system and therefore need to eat balanced. However, during some periods of student life, students think that food intake is insufficient and they encounter difficulties in balancing their diet, and therefore try to fill them by turning to DS, especially during confinement. Indeed, in addition to our diet, each human being has a psychological background that will have a major influence on feelings such as stress, anxiety or weariness [48].

Participants mainly consumed more than one type of DS (35\%). Braun and Venter [34] found that most students took vitamin, mineral and plant based DS. Self-administration of several DS can have serious side effects, caused by the activity of some constituents of DS with those of other DS or other drugs, also interactions between drugs and herbs [31]. For example, with ginkgo, antiplatelet or anticoagulant effects have been observed by Ulbricht et al., [49]. In addition, excessive consumption of vitamins and herbal supplements can interfere with the absorption of other nutrients by the body and thus lead to an unhealthy imbalance of the body's systems [50].

For consumer expectations, the main ones are fighting fatigue and stress [31] [43], solving health problems during exams and balancing diet. This result was confirmed by the observation of an association of the consumption of AC with eating habits $\left(\mathrm{Khi}^{2}=17.81 ; \mathrm{p}=0.037\right)$ as well as with the type of meal consumed $\left(\mathrm{Khi}^{2}=7.81 ; \mathrm{p}=0.037\right)$. About a third of students $(35.65 \%)$ prefer a healthy diet, thus, $30.69 \%$ report consuming meals prepared at home in advance $(30.69 \%)$; $17.82 \%$ eat fast food sandwiches, $39.24 \%$ eat healthy. Students therefore need to eat well to maintain general well-being or to improve mental and cognitive performance. They also want to improve athletic performance. This is not the case for Saudi students from Riyadh, 32.3\% of whom took supplements mainly for cosmetic reasons (for example, hair and skin health) [51]. Currently, the concept of body image is becoming a trend that continues to increase with the influence of the media. Thus, young people are increasingly aware of their appearance [52]. To achieve the desired body image, it is essential to have a good diet and to be physically active [53]. Eating a balanced diet strengthens the immune system. Some studies have shown that the effect of vitamin supplements on the immunity of individuals is difficult to measure and may also affect one component of the immune system but not another. In contrast, the main way to strengthen immunity against infections, including COVID 19, is to maintain good personal hygiene, healthy lifestyle and adequate nutritional intake [54] [55].

Most consumers say they buy DS in pharmacies and drugstores $(55.5 \%)$, on medical prescription $(32.77 \%)$ or on the advice of a pharmacist $(20.79 \%)$. The preference for purchasing these substances from pharmacies and drugstores is due to the confidence of students in traditional distribution places which are managed by specialists. These results are close to those observed by the INCA2 study (2006-2007) [56] and Khalfaoui in 2018 in Morocco [22], which noted that the consumption of DS is quite often recommended by a doctor (46,7\%); and 
purchased from pharmacies and drugstores. Japanese university students also reported buying DS mainly from pharmacies [57]. In contrast, Balzo et al. [58] reported in Italy that doctors ranked second after sports coaches.

$21.78 \%$ of participant's experience real satisfaction after consuming DS, and $34.65 \%$ feel they feel better. Khalfaoui, (2018) [22] and Jamal, (2016) [11] also noticed that respectively $27.8 \%$ and $31.6 \%$ are clearly satisfied. AlTamimi (2019) [51] also found that more than half of students in Riyadh, (Saudi Arabia) reported health benefits. In addition, $84.6 \%$ of Italian students declared that DS are very beneficial for health [58].

69.3\% of respondents have practiced physical activity during the past 12 months. The most active are those over 28 years old. These results are encouraging especially for this subpopulation. Managing stress and sleep through sport is also very important, especially during confinement. It helps you concentrate better; it is a natural antidepressant. Exercise improves mental health and cognitive function, and also plays a role in the management of depression and anxiety [59]. Our results also showed that boys engaged in more physical activity than girls. Similar results were observed by Mestaghanmi et al. in 2019 [23], who found that $65 \%$ of academics in Casablanca practiced physical activity, with a significant difference between the two sexes and that girls are less active than boys.

During confinement, the PA level is low at 22.7; moderate for $31 \%$ and high for 25.5. Student sports enthusiasts train at home. Moreover, in Morocco, during this period of confinement, the purchase of sports articles and equipment has increased sharply [60]. Thus, several students have started to practice individual sports and to follow sports lessons given by coaches, via social networks (instagram...).

Sports practice was associated with a higher probability of consuming DS $\left(\mathrm{Chi}^{2}=13.16 ; \mathrm{p}=0,000\right)$. Consumption is also associated with the level of PA $\left(\mathrm{Chi}^{2}=10.94 ; \mathrm{p}=0.027\right)$ and it is greater when the level of PA increases. Similar results have been observed by several authors [61] [62] [63]. Playing sports is generally considered a healthy habit. In this regard, some studies have indicated that DS users were more likely than non-users to participate in sports, suggesting that the consumption of these substances is part of a desire for a healthy life [64]. The main reason given, according to statements by athletes, is to improve sports performance, well-being as well as health [65].

Regarding the anthropometric parameters of our population, the average BMI is $22.64 \mathrm{~kg} / \mathrm{m}^{2} \pm 3.94 ; 65.35 \%$ have a normal build of which $50.49 \%$ are girls and $14.86 \%$ are boys. $8.15 \%$ are underweight and all of them are girls; $22.69 \%$ overweight; $3.81 \%$ obesity. Many of the participants present a normal build and even thinness, because generally, girls pay more attention to their appearance and their figure than boys [66]. Girls are also more likely than boys to be fat (overweight and obesity). Several factors could be at the origin of this weight gain. This could be related to diet and physical inactivity. In fact, obesity in college students is usually caused by an imbalance in energy intake and expenditure. 
This imbalance leads to an accumulation of reserves stored in fatty tissue, which can lead to many complications (type 2 diabetes, heart disease and cancer). A statistically significant association was observed between BMI classes and DS consumption [67].

For the use of substances posing a health risk (tobacco, alcohol and drugs), it is very rare in the study population. This could be explained by the desire of respondents to promote overall health by adopting healthy habits, especially since the majority of respondents are biologists [68]. Our results are different from those of Khelafa [69], who found that $17.5 \%$ consume alcohol and $9.8 \%$ cannabis and $24.6 \%$ tobacco in Fez, with a predominance of boys. Zerrouk [70] also observed, among young people in public establishments in the CenterNorth region of Morocco, higher frequencies of consumption. The prevalence of experimentation (use over the whole life) of all psychoactive products combined was $9.35 \%$, while the prevalence rates of recent use (in the last 12 months) and use current (over the past 30 days) were $7.48 \%$ and $6.28 \%$ respectively. Generally, the use of psychoactive products by students between the ages of 18 and 25 is much higher [71]. Alcohol and drugs are substances the consumption of which can also represent serious risks for the physical and psychological health and development of young people [72].

For students' beliefs, vis-à-vis DS, 32.5\% think they are harmless to health, $21.27 \%$ that regular consumption can prevent some diseases, while for $46.23 \%$, heavy drinking can pose a health risk. DS have been reported to be needed at all ages, are essentially harmless, and their regular consumption may prevent cancer and chronic disease [31].

DS could cause potential harmful side effects such as bone problems $(27.7 \%)$; hypervitaminosis (22.8\%); the development of some types of cancer (15.84); cardiovascular disorders (risk of cardiac arrest, etc.) (10.89\%); renal dysfunction problems (9.9\%); allergies (6.93\%), liver dysfunction (3.96\%), and 1.98\% believe that these substances increase the risk of mortality. Hypervitaminosis is often caused by self-medication and consumption without reading the labels and interacting with other substances. Intake of excessive amounts of vitamins and minerals can have harmful effects on health [73]. The use of some allergenic substances in the manufacturing process can affect hypersensitive people, which shows the importance of reading the labeling of these substances before use. Regular consumption of some DS has been reported in epidemiological and clinical trials to be associated with increased morbidity and mortality [74]. It can also cause significant damage, including side effects such as liver damage, cancer, heart attack or stroke [75]. Neurological disorders and hepatic toxicity have also been observed by Haller et al. [76]. In addition, most cases of renal and hepatic dysfunction associated with DS are due to supplementation intended for athletes and doping [77]. A number of deaths of apparently healthy young individuals have been attributed to the use of some DS. In-depth reviews of the literature have also shown that adults who do not consume vitamin and mineral supplements are quite often healthy [78]. Although the role of DS in preventing nutri- 
tional deficiencies is well established, there is insufficient evidence for that in preventing death from cardiovascular disease and cancer [79].

The toxicity of DS could be linked to some of their component. Thus, 30\% think it is related to food additives used in their manufacture, $21 \%$ to some vitamins, $15 \%$ to antioxidants; $15 \%$ multi-component; $10 \%$ to herbal products. Since the start of the Covid19 pandemic, many people have tended to store DS and drugs in order to protect themselves against Covid19 and strengthen their immune system [80]. The role of some micronutrients as support agents in the treatment and prevention of respiratory tract infection has been demonstrated by several studies [81]. Although the use of vitamins in doses higher than those recommended is safe, moderate consumption is desirable. Vitamins and minerals are involved in the strengthening of the immune system and participate in many biochemical processes and in well-being [82]. An appropriate intake of micronutrients is therefore essential at each stage of growth, and particularly in some physiological conditions (stressful situations and deficiencies, advanced age). Some studies have reported the deleterious effects of excessive supplementation of antioxidants and especially synthetics (A, E, C and $\beta$-carotene) which are often used in many preventive and long-term therapeutic medical applications. However, they can lead to hypervitaminosis and even a potential toxic effect. [83]. For herbal supplements or herbal extracts, they can be toxic when used for improper indications, or in an inappropriate manner, excessive or for a prolonged period. For example, excessive doses of vitamin D cause hyperkalemia; similarly, excessive and prolonged vitamin A intake can lead to osteoporosis and hepatotoxicity [84]. Constituents of some herbal products can increase the risk of side effects and induce toxicity [85]. Some weight loss DS contain several alkaloids, which can cause high blood pressure, increase the risk of arrhythmias, heart attacks and stroke [86]. In addition, other constituents can lead to doping (caffeine...) especially in athletes, with excessive consumption, especially for strength sports (such as body building, weight lifting...) are harmful to consumer health, rather than improving it [87].

Several substances of plant origin may also contain androgenic steroids [16]. The presence of anabolic and exogenous androgens in DS, are converted into testosterone, above normal levels. They are likely to promote muscle mass, but also suppress testicular testosterone production and exert negative control over the release of pituitary gonadotropins [88]. Excess circulating testosterone is converted to estradiol, providing feedback to the pituitary gland. High estrogen concentrations can cause estrogenic side effects [89]. At the end of a supplementation cycle, testosterone levels in the body can be very low.

\section{Conclusions}

Academics in Casablanca consume a lot of DS during the COVID 19 pandemic. These substances help supplement the normal diet and prevent disease, but uncontrollable use can be ineffective in the absence of vitamin or mineral deficien- 
cies and can also be harmful. Drugs and DS used together can cause many unwanted side effects that can lead to serious complications.

It is therefore advisable to raise awareness among students through TV spots and to include specific courses in university study programs for health sectors, covering the indications, interactions and potential adverse effects of DS.

Students must also be encouraged to adopt a healthy lifestyle; a diversified diet is balanced, with physical activity, which is essential for the preservation of good health.

\section{Acknowledgements}

We would like to warmly thank all the students of the Ben M'Sik Faculty of Science (University Hassan II of Casablanca, Morrocco), who kindly participated in this study.

\section{Conflicts of Interest}

The authors declare no conflicts of interest regarding the publication of this paper.

\section{References}

[1] Zhu, N., Zhang, D., Wang, W., Li, X., Yang, B., Song, J., Zhao, X., Huang, B., Shi, W., Lu, R., Niu, P., Zhan, F., et al. (2020) A Novel Coronavirus from Patients with Pneumonia in China, 2019. New England Journal of Medicine, 382, 727-733. https://doi.org/10.1056/NEJMoa2001017

[2] OMS (World Health Organization) (2019) Faire face au stress durant la flambée de maladie à coronavirus COVID-19.

https://www.who.int/fr/emergencies/diseases/novel-coronavirus-2019/advice-for-p $\underline{\mathrm{ub}-}$ lic?gclid=Cj0KCQjwppSEBhCGARIsANIs4p4Q01M9EpH-3DO2gSl0ESUZ8cnmjvS tqASUyNcz-nBlFON5PpDQ6PUaAoMREALw wcB

[3] Mengin, A., Allé, M.C., Rolling, J., Ligier, F., Schroder, C., Lalanne, L., Berna, F., Jardri, R., Vaiva, G., Geoffroy, P.A., Brunault, P., Thibaut, F., Chevance, A. and Giersch, A. (2020) Conséquences psychopathologiques du confinement. L'Encéphale, 46, S43S52. https://doi.org/10.1016/j.encep.2020.04.007

[4] Polamarasetti, P. and Danik, M. (2020) Nutrition Planning during the COVID-19 Pandemic for Aging Immunity. Bioactive Compounds in Health and Disease, 3, 109-123. https://doi.org/10.31989/bchd.v3i7.733

[5] Gur, J., Mawuntu, M. and Martirosyan, D. (2018) FFC's Advancement of Functional Food Definition. Functional Foods in Health and Disease, 8, 385-397.

https://doi.org/10.31989/ffhd.v8i7.531

[6] Monceau, Chr., Blanche-Barbat, E. and Echampe, J. (2002) La consommation alimentaire depuis quarante ans, de plus en plus de produits élaborés. INSEE Première, No. 846, 4 p. https://www.epsilon.insee.fr/jspui/bitstream/1/442/1/ip846.pdf

[7] Valette, J. (2015) Les compléments alimentaires (définition, aspects réglementaires, cas pratique: un médicament qui évolue en complément alimentaire). Thèse présentée à l'Université de Limoges, Faculté de Pharmacie, pour l'obtention du Doctorat en Pharmacie, $123 \mathrm{p}$. 
[8] Bardou-Boisnier, S. and Caillaud, K. (2015) Les dispositifs informationnels sur les compléments alimentaires: Une affaire de santé publique. L'alimentation, une affaire publique? Questions de communication, 27, 79-104.

https://doi.org/10.4000/questionsdecommunication.9705

[9] Marzec, A., Skrzypek, M. and Marzec, Z. (2018) Dietary Supplements as a Challenge for Contemporary Public Health: Scale of the Phenomenon, Health Risk, Legal Regulations. Sciendo. Polish Journal of Public Health, 128, 30-35.

https://doi.org/10.2478/pjph-2018-0006

[10] De Villepin, D., Breton, Th., Clément, P., Bertrand, X. and Bussereau, D. (2011) Décret n²006-352 du 20 Mars 2006 relatif aux compléments alimentaires. NOR: ECOC0500166D. Version consolidée au 24 Avril 2020. Legifrance, le service public de la diffusion des droits.

https://www.legifrance.gouv.fr/loda/id/JORFTEXT000000638341/

[11] Jamal, F.Z. (2016) La consommation des compléments alimentaires au Maroc, 2015. Thèse présentée à l'Université Mohamed 5, Faculté de Médecine et de Pharmacie de Rabat pour l'obtention du Doctorat en Pharmacie, $161 \mathrm{p}$.

[12] Thomsen, P.A., Terry, R.D. and Amos, R.J. (1987) Adolescents' Beliefs about and Reasons for Using Vitamin/Mineral Supplements. Journal of American Dietetic Association, 87, 1063-1065.

[13] Wolfe, R.R. (2000) Protein Supplements and Exercise. American Journal of Clinical Nutrition, 72, 551S-557S. https://doi.org/10.1093/ajcn/72.2.551S

[14] Derbré, S. (2010) Tour d'horizon des compléments alimentaires à base de plantes. Actualités pharmaceutiques, 49, 20-31.

https://doi.org/10.1016/S0515-3700(10)70694-7

[15] Parlement Européen (2008) RÈGLEMENT (CE) No 178/2002 DU PARLEMENT EUROPÉEN ET DU CONSEIL du 28 janvier 2002, (Article 14).

https://eur-lex.europa.eu/LexUriServ/LexUriServ.do?uri=CONSLEG:2002R0178:20 080325:FR:PDF\#: :text=La\%20libre\%20circulation\%20des\%20denr\%C3\%A9es, \%C 3\%89tat\%20membre\%20\%C3\%A0\%20l'autre

[16] Ronis, M.J.J., Pedersen, K.B. and Watt, J. (2018) Adverse Effects of Nutraceuticals and Dietary Supplements. Annual Review of Pharmacology and Toxicology, 58, 583601. https://doi.org/10.1146/annurev-pharmtox-010617-052844 https://www.ncbi.nlm.nih.gov/pmc/articles/PMC6380172/pdf/nihms-1012635.pdf

[17] Martin, A. (2001) Apports nutritionnels conseillés pour la population française. Tec et Doc, $3^{\text {ème }}$ Edition. (Retirage 2018). Lavoisier, Paris, 438.

[18] NIH (National Institutes of Health) (2001) Dietary Supplement What You Need to Know. National Institutes of Health (NIH), Bethesda.

https://ods.od.nih.gov/factsheets/WYNTK-Consumer/

[19] ANSES (Agence nationale de sécurité sanitairede l'alimentation, de l'environnementet du travail) (2016) Compléments alimentaires destinés aux sportifs: des risques pour la santé pour des bénéfices incertains.

https://www.anses.fr/fr/content/compl\%C3\%A9ments-alimentaires-destin\%C3\%A9 s-aux-sportifs-des-risques-pour-la-sant\%C3\%A9-pour-des-b\%C3\%A9n\%C3\%A9fic $\underline{\text { es }}$

[20] Pope Jr., H.G., Wood, R.I., Rogol, A., Nyberg, F., Bowers, L. and Bhasin, S. (2014) Adverse Health Consequences of Performance-Enhancing Drugs: An Endocrine Society Scientific Statement. Endocrine Reviews, 35, 341-375. https://doi.org/10.1210/er.2013-1058

[21] Dwyer, J., Coates, P.M. and Smith, M.J. (2018) Dietary Supplements: Regulatory 
Challenges and Research Resources. Nutrients, 10, Article No. 41, 24 p. https://doi.org/10.3390/nu10010041 https://www.ncbi.nlm.nih.gov/pmc/articles/PMC5793269/pdf/nutrients-10-00041.p df

[22] Khalfaoui, Y. (2018) Le profil des consommateurs de compléments alimentaires au Maroc.. Thèse de Doctorat de Médecine, présentée à l’Université Sidi Mohamed Ben Abdellah, Faculté de Médecine et de Pharmacie, Fès, 107 pages.

[23] Mestaghanmi, H., Labriji, A., Kehailou, F.Z., Mahfoud, F.Z., Battai, M., Jabari, M., M’Touguy, I. and El Amrani, S. (2019) Relation entre obésité, habitudes alimentaires et hygiène de vie d'une population universitaire de Casablanca, Maroc. American Journal of Innovative Research \& Applied Sciences, 9, 153-166.

https://www.american-jiras.com

[24] Mestaghanmi, H., Labriji, A., M'Touguy, I., Kehailou, F.Z., Idhammou, S., Kobb, N., Mahfoud, F.Z., Ibrahim Khalil, A. and El Amrani, S. (2018) Impact of Eating Habits and Lifestyle on the Oral Health Status of a Casablanca's Academic Population. Open Access Library Journal, 5, e4967.

https://doi.org/10.4236/oalib.1104967 https://www.oalib.com/articles/5300480\#.YKYmoagzbIU

[25] Tsuyoshi, C., Kobayashi, E., Okura, T., Sekimoto, M., Mizuno, H., Saito, M. and Umegak, K. (2020) An Educational Intervention Improved Knowledge of Dietary Supplements in College Students. BMC Public Health, 20, Article No. 633, 12 p. https://doi.org/10.1186/s12889-020-08786-3 https://bmcpublichealth.biomedcentral.com/track/pdf/10.1186/s12889-020-08786-3 .pdf

[26] Association Médicale Mondiale (AMM) (2013) Déclaration d'Helsinki de L'AMMPrincipes éthiques applicables à la recherche médicale impliquant des êtres humains. https://www.wma.net/fr/policies-post/declaration-dhelsinki-de-lamm-principes-eth iques-applicables-a-la-recherche-medicale-impliquant-des-etres-humains/\#: :text= L'Association\%20M\%C3\%A9dicale\%20Mondiale\%20(AMM,et\%20sur\%20des\%20d onn\%C3\%A9es\%20identifiables

[27] WHO (World Health Organization) (2000) Obesity: Preventing and Managing the Global Epidemic: Report of a WHO Consultation. WHO Technical Report Series No. 894, World Health Organization, Geneva. https://apps.who.int/iris/handle/10665/42330

[28] IPAQ (International Physical Activity Questionnaire) (2002) International Physical Activity Questionnaire Short Last 7 Days Self-Administered Format for Use with Young and Middle-Aged Adults (15-69 Years).

https://sites.google.com/site/theipaq/questionnaire links

[29] Janus, P. and Reguła, J. (2009) Popularność suplementów diety wśród młodzieży. [Popularity of Diet Supplements Determinants of the Use of Dietary Supplements among School Students, among the Young People]. Postępy Techniki Przetwórstwa Spożywczego, 2, 94-98 (in Polish, English Abstract).

[30] Lieberman, H.R., Marriott, B.P., Williams, C., Judelson, D.A., Glickman, E.L., Geiselman, P.J., Dotson, L. and Mahoney, C.R. (2015) Patterns of Dietary Supplement Use among College Students. Clinical Nutrition, 34, 976-985.

https://doi.org/10.1016/j.clnu.2014.10.010

[31] Sirico, F., Miressi, S., Castaldo, C., Spera, R., Montagnani, S., Di Meglio, F., et al. (2018) Habits and Beliefs Related to Food Supplements: Results of a Survey among Italian Students of Different Education Fields and Levels. PLoS ONE, 13, e0191424. https://doi.org/10.1371/journal.pone.0191424 
[32] CREDOC (Centre de Recherche pour l'Etude et l'Observation des Conditions de Vie) (2012) Consommation de compléments alimentaires en France: profil des consommateurs et contribution à l'équilibre nutritionnel. dans les Cahiers de Nutrition et de Diététique, Flash Info, Synadiet (syndicat national des compléments alimentaires), $2 \mathrm{p}$.

https://www.synadiet.org/sites/default/files/mediatheque/files/fi ndeg255 - parutio $\underline{\mathrm{n} \text { de letude credoc - profil des consommateurs et contribution a lequilibre } \mathrm{n}}$ utritionnel.pdf

[33] Ziegler, P.J., Nelson, J. and Jonnalagadda, S.S. (2003) Use of dietary supplements by elite figure skaters, International journal of sport nutrition and exercise metabolism, 13, 266-276. https://doi.org/10.1123/ijsnem.13.3.266

[34] Braun, M. and Venter, I. (2008) Use of Dietary Supplements, and Awareness and Knowledge of the Recommended Fruit and Vegetable Intakes and Consumption of Health Food Store Customers in the Cape Town City Bowl. South African Journal of Clinical Nutrition, 21, 323-330. https://doi.org/10.1080/16070658.2008.11734174

[35] Dubecq, C., Daniel, Y., Aigle, L. and Bigard, X. (2014) Utilisation des compléments alimentaires à visée ergogénique chez les militaires français: prévalence et modes de consommation lors d'une opération extérieure. Science et Sports, 29, 188-195. https://doi.org/10.1016/j.scispo.2014.06.001

[36] Grzymisławska, M., Puch, E.A., Zawada, A. and Grzymisławski, M. (2020) Do Nutritional Behaviors Depend on Biological Sex and Cultural Gender? Advances in Clinical and Experimental Medicine, 29, 165-172, 8 p.

[37] Soni, M.G., Thurmond, T.S., Miller, E.R., Spriggs, T., Bendich, A. and Omaye, S.T. (2010) Safety of Vitamins and Minerals: Controversies and Perspective. Toxicol Sci, 118, 348-355. https://doi.org/10.1093/toxsci/kfq293

[38] Bonillo, G. (2019) Les challenges et opportunités des compléments alimentaires. Une étude Harris Interactive à l'occasion du salon Nutriform' Business Days (Diaporama). https://harris-interactive.fr/catalogue/pages/complements alimentaires.html

[39] Al-Johani, W.M., Al-Dawood, K.M., Abdel Wahab, M.M. and Yousef, H.A. (2018) Consumption of Vitamin and Mineral Supplements and Its Correlates among Medical Students in Eastern Province, Saudi Arabia. Journal of Family and Community Medicine, 25, 169-174.

[40] Agathe, M. (2018) Les étudiants et leur alimentation. Université de Bretagne Occidentale UFR Lettres et Sciences Humaines. Mémoire de Master 1 Mention Psychologie Spécialité Représentations sociales, pratiques et interventions. 195 p.

[41] Kang, H., Joo, H.H., Choi, K.D., Lee. D. and Moon, J. (2017) Complementarity in Dietary Supplements and Foods: Are Supplement User's Vegetable Eaters? Food \& Nutrition Research, 61, Article ID: 1361769.

[42] Lieberman, H.R. (2007) Cognitive Methods for Assessing Mental Energy. Nutritional Neuroscience, 10, 229-242. https://doi.org/10.1080/10284150701722273

[43] O'Connor, J. (2006) Mental Energy: Assessing the Mood Dimensions. Nutrition Reviews, 64, S7-S9. https://doi.org/10.1111/j.1753-4887.2006.tb00256.x

[44] Bertrais, S., Preziosi, P., Mennen, L., Galan, P., Hercberg, S. and Oppert, J.M. (2004) Sociodemographic and Geographic Correlates of Meeting Current Recommendations for Physical Activity in Middle-Aged French Adults: The Supplémentation en Vitamines et Minéraux Antioxydants (SUVIMAX) Study. American Journal of Public Health, 94, 1560-1566. https://doi.org/10.2105/AJPH.94.9.1560

https://ajph.aphapublications.org/doi/full/10.2105/AJPH.94.9.1560 
[45] Unlu, N. (2016) Surpoids, régimes amaigrissants et produits minceurs: Evaluation, mises en gardes et conseils du pharmacien d'officine. Thèse présentée à l'Université de Lorraine, Faculté de Pharmacie, pour l'obtention du Diplôme de Doctorat en Pharmacie, $109 \mathrm{p}$.

[46] Synadiet (Syndicat National des compkements alimentaires) (2016) Prévenir plutôt que guérir: Une urgence sociale, médicale et économique. Dossier de presse, $16 \mathrm{p}$. https://www.synadiet.org/sites/default/files/press/files/dp synadiet web.pdf

[47] Devaux, S. and Brisard, M. (2016) Consommation de compléments alimentaires chez les triathlètes: résultats d'une enquête régionale. Nutrition Clinique et Métabolisme, 30, 118. https://doi.org/10.1016/j.nupar.2016.04.031

[48] Soufis, J. (2017) La nutrition des étudiants de première année commune aux études de sante: optimisation de leur cognition. Thèse présentée à l’Université Grenoble Alpes, Faculté de Pharmacie de Grenoble, pour l'obtention du Doctorat en Pharmacie, $124 \mathrm{p}$.

[49] Ulbricht, C., Chao, W., Rusie-Seamon, E., Weissner, W. and Woods, J. (2008) Clinical Evidence of Herb-Drug Interactions: A Systematic Review by the Natural Standard Research Collaboration. Current Drug Metabolism, 9, 1063-1120. https://doi.org/10.2174/138920008786927785

[50] Eisenberg, D., Kessler, R., Foster, C., Norlock, F., Calkins, D. and Deblanco, T. (1993) Unconventional medicine in the United States, The New England Journal of Medicine, 28, 246-252. https://doi.org/10.1056/NEJM199301283280406

[51] Al Tamimi, J.Z. (2019) Awareness of the Consumption of Dietary Supplements among Students in a University in Saudi Arabia. Journal of Nutrition and Metabolism, 2019, Article ID: 4641768, 10 p. https://doi.org/10.1155/2019/4641768

[52] Yamamiya, Y., Cash, T.F., Melnyk, S.E., Posavac, H.D. and Posavac, S.S. (2005) Women's Exposure to Thin-and-Beautiful Media Images: Body Image Effects of Media-Ideal Internalization and Impact-Reduction Interventions. Body Image, 2, 74-80. https://doi.org/10.1016/j.bodyim.2004.11.001

[53] Yarasheski, K., Zachwieja, J.J. and Bier, D.M. (1993) Acute Effects of Resistance Exercise on Muscle Protein Synthesis Rate in Young and Elderly Men and Women. American Journal of Physiology-Endocrinology and Metabolism, 265, E210-E214. https://doi.org/10.1152/ajpendo.1993.265.2.E210

[54] Sohrabi, C., Alsafi, Z., O’Neill, N., Khan, M., Kerwan, A., Al-Jabir, A., Iosifidis, C. and Agha, R. (2020) World Health Organization Declares Global Emergency: A Review of the 2019 Novel Coronavirus (COVID-19). International Journal of Surgery, 26, 71-76. https://doi.org/10.1016/j.ijsu.2020.02.034

[55] Zavascki, A. and Falci, D.R. (2020) Clinical Characteristics of Covid-19 in China. World, 27, Article No. 33.

[56] AFSSA (Agence française de sécurité sanitaire des aliments) (2009) Étude individuelle nationale des consommations alimentaires 2 (INCA 2) 2006-2007. Agence française de sécurité sanitaire des aliments, Nancy, $228 \mathrm{p}$. https://www.anses.fr/fr/system/files/PASER-Ra-INCA2.pdf

[57] Kobayashi, E., Sato, Y., Umegaki, K. and Chiba, T. (2017) The Prevalence of Dietary Supplement Use among College Students: A Nationwide Survey in Japan. Nutrients, 9, Article No. 1250. https://doi.org/10.3390/nu9111250

[58] Balzo, V.D., Vitiello, V., Germani, A., Donini, L.M., Poggiogalle, E. and Pinto, A. (2014) A Cross-Sectional Survey on Dietary Supplements Consumption among Italian Teenagers. PLOS ONE, 9, e100508. https://doi.org/10.1371/journal.pone.0100508

[59] Institut national de la santé et de la recherche médicale (Inserm) (2008) Activité 
physique: Contextes et effets sur la santé. Rapport. Vol. 12, Les éditions Inserm, Paris, 811 p. http://hdl.handle.net/10608/97

[60] Kh, K. (2020) Fort engouement pour les équipements sportifs à cause des mesures de restriction. Media 24, 5 octobre 2020 à 13h46, Modifié 11 avril 2021 à 2 h48.

https://www.medias24.com/2020/10/05/fort-engouement-pour-les-equipements-sp ortifs-a-cause-des-mesures-de-restriction/

[61] Kennedy Eileen, T., Hanqi, L. and Houser, R.F. (2013) Dietary Supplement Use Pattern of U.S. Adult Population in the 2007-2008 National Health and Nutrition Examination Survey (NHANES). Ecology of Food and Nutrition, 52, 76-84. https://doi.org/10.1080/03670244.2012.706000

[62] Pouchieu, C., Lévy, R., Faure, C., Andreeva, V., Galan, P., Hercberg, S. and Touvier, M. (2013) P041 Consommation de compléments alimentaires pendant la grossesse et facteurs socioéconomiques, alimentaires et de mode de vie associés. C. Nutrition Clinique et Métabolisme, 27, S77-S78. https://doi.org/10.1016/S0985-0562(13)70374-1

[63] Pouchieu, C. (2014) Compléments alimentaires: consommation et facteurs associés en population générale et dans des groupes spécifiques-modulation du risque de cancer. Thèse présentée à l'Université paris 13 «équipe de recherche en épidémiologie nutritionnelle» pour obtenir le grade de Doctorat de l'Université Paris 13, Discipline: Epidémiologie-Santé Publique, 264 p.

[64] Bailey, R.L., Gahche, J.J., Miller, P.R. and Dwyer, J.T. (2013) Why US Adults Use Dietary Supplements. JAMA Internal Medicine, 173, 355-361. https://doi.org/10.1001/jamainternmed.2013.2299

[65] Nichter, M., Thompson, J.J. (2006) For My Wellness, Not Just My Illness: North Americans' Use of Dietary Supplements. Culture, Medicine and Psychiatry, 30, 175222. https://doi.org/10.1007/s11013-006-9016-0

[66] Mestaghanmi, H., Labriji, A., Kehailou, F.Z., Martaj, M., M’Touguy, I., Jabari, M., Kaoutar, S. and El Amrani, S. (2020) Consumption of Light Products and Prevalence of Obesity among a Population of Academics in Casablanca, Morocco. International Journal of Advances in Scientific Research and Engineering, 6, 150-165. https://doi.org/10.31695/IJASRE.2020.33767

[67] Burnett, A.J., Katherine, M., Livingstone, I.D., Woods, J.L. and McNaughton, S.A. (2017) Dietary Supplement Use among Australian Adults: Findings from the 20112012 National Nutrition and Physical Activity Survey. Nutrients, 9, Article No. 1248, 12 p. https://doi.org/10.3390/nu9111248

[68] Chiou, W., Yang, C. and Wan, C.S. (2011) Ironic Effects of Dietary Supplementation: Illusory Invulnerability Created by Taking Dietary Supplements Licenses HealthRisk Behaviors. Psychological Science, 22, 1081-1086. https://doi.org/10.1177\%2F0956797611416253

[69] Khelafa, S. (2013) Les prévalences du tabagisme et de la toxicomanie en milieu scolaire à Fès: Enquête auprès de 1070 élèves. Thèse présentée à l'Université Sidi Mohammed Ben Abdellah faculté de médecine et de pharmacie FES, pour l'obtention du diplôme du Doctorat en Médecine, 79 p.

[70] Zerrouq, B. (2016) Profil Epidémiologique et Toxicologique de l'Usage des Substances Psychoactives et des Comportements Suicidaires chez les Adolescents Marocains. Thèse présentée à Université Sidi Mohammed Ben Abdellah, Faculté des Sciences Dhar El Mahraz, Pour l'obtention du Doctorat en Physiologie, Pharmacologie, Epidémiologie \& Santé Environnementale, 203 p.

[71] Beck, F., Legleye, S., Guilbert, P. and Pretti-Watel, P. (2005) Les usages de produits 
psychoactifs des étudiants. Psychotropes, 11, 31-51.

[72] National Institutes of Health (NIH) (2020) Common Comorbidities with Substance Use Disorders Research Report Part 1: The Connection between Substance Use Disorders and Mental Illness. National Institutes of Health, Bethesda.

https://www.drugabuse.gov/publications/research-reports/common-comorbidities-s ubs-

tance-use-disorders/part-1-connection-between-substance-use-disorders-mental-ill $\underline{\text { ness }}$

[73] Dupin, H. (1992) Alimentation et nutrition humaine. Esf Editeur, Paris, Amazon France. $1533 \mathrm{p}$.

[74] Mursu, J., Robien, K., Harnack, I.J., Park, K. and Jacobs, J.R. (2011) Dietary Supplements and Mortality Rates in Older Women: The Iowa Women's Health Study. Archives of Internal Medicine, 171, 1625-1633.

https://doi.org/10.1001/archinternmed.2011.445

[75] Rizos, E.C., Ntzani, E.E, Bika, F., Kostapanos, M. and Elisaf, M.S. (2012) Association between oméga-3 Fatty Acid Supplementation and Risk of Major Cardiovascular Disease Events: A Systematic Review and Meta-Analysis. JAMA, 308, 1024-1033. https://doi.org/10.1001/2012.jama.11374

[76] Haller, C., Kearney, T., Bent, S., Ko, R., Benowitz, N. and Olson, K. (2008) Dietary Supplement Adverse Events: Report of a One-Year Poison Center Surveillance Project. Journal of Medical Toxicology, 4, 84-92. https://doi.org/10.1007/BF03160960

[77] ANSES (Agence nationale de sécurité sanitaire de l'alimentation, de l'environnement et du travail) (2016) Compléments alimentaires destinés aux sportifs: Des risques pour la santé pour des bénéfices incertains.

https://www.anses.fr/fr/content/compl\%C3\%A9ments-alimentaires-destin\%C3\%A9 s-aux-sportifs-des-risques-pour-la-sant\%C3\%A9-pour-des-b\%C3\%A9n\%C3\%A9fic $\underline{\text { es }}$

[78] Fortmann, S.P., Burda, B.U., Senger, C.A. and Whitlock, E.P. (2013) Vitamin and Mineral Supplements in the Primary Prevention of Cardiovascular Disease and Cancer: An Updated Systemic Evidence Review for the US. Preventative Services Task Force. Annals of Internal Medicine, 159, 824-834. https://doi.org/10.7326/0003-4819-159-12-201312170-00729

[79] Schwingshackl, L., Boeing, H., Stelmach-Mardas, M., Gottschald, M., Dietrich, S., Hoffmann, G. and Chaimani, A. (2017) Dietary Supplements and Risk of CauseSpecific Death, Cardiovascular Disease, and Cancer: A Systematic Review and MetaAnalysis of Primary Prevention Trials. Advances in Nutrition, 8, 27-39. https://doi.org/10.3945/an.116.013516

[80] Gombart, A.F., Pierre, A. and Maggini, S. (2020) A Review of Micronutrients and the Immune System-Working in Harmony to Reduce the Risk of Infection. Nutrients, 12, Article No. 236. https://doi.org/10.3390/nu12010236

[81] Martineau, A.R., Jolliffe, D.A., Hooper, R.L., Greenberg, L., Aloia, J.F., Bergman, P., Dubnov-Raz, G., Esposito, S., Ganmaa, D., Ginde, A.A., et al. (2017) Vitamin D Supplementation to Prevent Acute Respiratory Tract Infections: Systematic Review and Meta-Analysis of Individual Participant Data. BMJ, 356, i6583.

https://doi.org/10.1136/bmj.i6583

[82] Di Matteo, G., Spano, M., Grosso, M., Salvo, A., Ingallina, C., Russo, M., Ritieni, A. and Mannina, L. (2020) Food and COVID-19: Preventive/Co-therapeutic Strategies Explored by Current Clinical Trials and in Silico Studies. Foods, 9, Article No. 1036, 18 p. https://doi.org/10.3390/foods9081036 
[83] Maciej, R. and Grzegorczyk, K. (2012) Adverse Effects of Antioxidative Vitamins. International Journal of Occupational Medicine and Environmental Health, 25, 105121. https://link.springer.com/article/10.2478/S13382-012-0022-x https://doi.org/10.2478/S13382-012-0022-x

[84] Mulholland, C.A. and Benford, D.J. (2007) What Is Known about the Safety of Multivitamin-Multimineral Supplements for the Generally Healthy Population? Theoretical Basis for Harm. American Journal of Clinical Nutrition, 85, 318S-322S. https://doi.org/10.1093/ajcn/85.1.318S

[85] Bergeron, M.F., Senchina, D.S., Burke, L.M., Stear, S.J. and Castell, L.M. (2010) A-Z of Nutritional Supplements: Dietary Supplements, Sports Nutrition Foods and Ergogenic Aids for Health and Performance, Part 7. British Journal of Sports Medicine, 44, 389-391.

[86] Condemine-Piron, C. (2008) D’une analyse du risque sanitaire et sportif des consommations de compléments alimentaires à la mise en place d'un dispositif de nutrivigilance pilote à Montpellier. AMPD Languedoc Roussillon. Lettre d Actualités de Février 2008.

[87] Canter, P.H. and Ernst, E. (2004) Herbal Supplement Use by Persons Aged over 50 Years in Britain: Frequently Used Herbs, Concomitant Use of Herbs, Nutritional Supplements and Prescription Drugs, Rate of Informing Doctors and Potential for Negative Interactions. Drugs and Aging, 21, 597-605. https://doi.org/10.2165/00002512-200421090-00004

[88] Karavolos, S., Reynolds, M., Panagiotopoulou, N., McEleny, K., Scally, M. and Quinton, R. (2015) Male Central Hypogonadism Secondary to Exogenous Androgens: A Review of the Drugs and Protocols Highlighted by the Online Community of Users for Prevention and/or Mitigation of Adverse Effects. Clinical Endocrinology, 82, 624-632. https://doi.org/10.1111/cen.12641

[89] Rahnema, C.D., Lipshultz, L.I., Crosnoe, L.E., Kovac, J.R. and Kim, E.D. (2014) Anabolic Steroid-Induced Hypogonadism: Diagnosis and Treatment. Fertil Steril, 101, 1271 1279. https://doi.org/10.1016/j.fertnstert.2014.02.002 